\title{
The Participation of a Brazilian Family in Psychosocial Counseling of Obese Children and Adolescents*
}

\author{
Maria Alexina Ribeiro, Vladimir de Araújo Albuquerque Melo, Heron Flores Nogueira, \\ Marília Marques da Silva, Ilckmans Bergma Moreira Mugarte, Aldenira Barbosa Cavalcante, \\ Jamile Xavier Fernandes de Castro \\ Catholic University of Brasilia (UCB), Brasília, Brazil
}

\begin{abstract}
Regarded by the World Health Organization as a public health matter, an analysis of the statistics shows a significant increase of obesity in children, adolescents, and adults in many parts of the world. Family inclusion in childhood obesity treatment has been recommended in many scientific studies, and an intervention including families presupposes knowledge of their dynamics and influence on disease onset and maintenance. In this sense, the present work aims to present data of research with one family that is part of psychosocial counseling of families with obese children and adolescents. The sample family is composed of the father, 43 years old, the mother, 36 , and their obese daughter, 10, currently weighing 178 pounds and 1.25 meters in height. The data were collected through an interview focusing on the family life cycle, from the new couple stage through the present. Data analysis revealed that the following features interfere with child obesity treatment: parental omission in the daughter's diet; the mother's illness complicating fulfillment of parental functions; parents' marital difficulties; lack of marital harmony between parents endangering their complicity in the child's protection and education; and family resistance in accepting and adhering to child obesity treatment. The data reinforce the need for understanding dynamics of families with obese children and for family inclusion in childhood obesity treatment.
\end{abstract}

Keywords: childhood obesity, family, systems approach

\section{Introduction}

The diet has always held an important position, both for survival and as a part of social and interpersonal human relations. From the time of Greek banquets and Roman food symbolism, through the advent of fast food restaurants that put an end to the ritual that surrounded mealtimes in the 1970s, eating habits followed politics and the sociocultural changes that influenced human behavior in all cultures. Nowadays, we see a mix between

\footnotetext{
*Acknowledgements: This study is part of a research project funded by CNPq (National Counsel of Technological and Scientific Development) and was developed with the participation of the following students who joined the Scientific Initiation program: Flora Mota de Paula, Ana Paula Oliveira, Denise Mourão de Abreu, Maria Teresa Messias, Lidiane Guimarães Monte, Luiz Henrique Cruz, Flávia Valadares, Larissa Carvalho, and Karine Vilas Boas de Moura.

Maria Alexina Ribeiro, MSc., Psy.D., professor, Catholic University of Brasilia (UCB).

Vladimir de Araújo Albuquerque Melo, Master, Catholic University of Brasília (UCB).

Heron Flores Nogueira, MSc., Ph.D. student, Catholic University of Brasília (UCB).

Marília Marques da Silva, Psy.D., professor, Catholic University of Brasília (UCB).

Ilckmans Bergma Moreira Mugarte, MSc., Ph.D. student, Catholic University of Brasília (UCB).

Aldenira Barbosa Cavalcante, MSc., Ph.D. student, Catholic University of Brasília (UCB).

Jamile Xavier Fernandes de Castro, Catholic University of Brasília (UCB).
} 
low cost and standardized food consumption and out-of-home meals, in addition to the comforts of modern life that result in a sedentary lifestyle. One of the consequences of this combination is the increase of obesity in children, adolescents, and adults in many parts of the world.

Obesity is a chronic disease, of multifactorial etiology and numerous associated complications, according to World Health Organization (2014a). Considered one of the most serious public health problems around the world at this time, obesity has high morbidity and mortality rates, worrying governments and the scientific community alike. Described as "abnormal or excessive fat accumulation that may impair health", obesity can promote the development of severe diseases. It is presumed that over 300 million adults in the world are obese and, together with overweight people, they rank the fifth among the most deadly risk factors in the world. At least 2.8 million adults die every year due to obesity and excessive weight (World Health Organization, 2014b).

In Brazil, the statistics are also alarming. According to the most recent research done by Vigilance System of Chronic Disease Risk Factors by Telephone Survey (Ministry of Health/Brazil, 2013), 17.4\% of the Brazilian population is obese, while $51 \%$ are overweight. These figures are up from the previous years' obesity rate of $15.8 \%$ and overweight rate of $48.5 \%$ (Ministry of Health/Brazil, 2013). The increasing tendency in Brazil confirms epidemic proportions of obesity all over the world.

It is estimated that half of all obese children become obese adults, with enhanced possibilities of suffering advanced effects, like Diabetes Mellitus, cardiovascular diseases, arterial hypertension, orthopedic and joint problems, higher risk of surgery, among other complications (Kunkel, Oliveira, \& Peres, 2009). Camargo, Barros Filho, Antonio, and Giglio (2013) emphasize of the influence obese parents exercise in their children's lives; inappropriate dietary practices can contribute to permanent childhood obesity, as environmental conditions are one of the factors most contributing to obesity, and in case of an absence of change inhabits, rarely do obese children lose weight and remain at a healthy weight.

Among the 10 factors in obesity to which World Health Organization (2014a) calls attention, two involve the social and family environment. The first one asserts that positive societal and health messaging are fundamental to shape individuals' choices and prevent obesity. The second is that children's diet, choices, and physical activity are all influenced by their environment. Moraes and Dias (2012) attribute the epidemic prevalence to changes in families' lifestyle due to the progress of urbanization, industrialization, professionalization of women, the high quality of life, and education, among other social changes that have increased access to sweet and fatty foods.

Research into childhood obesity has demonstrated the significant role of family as a factor contributing to the disease's emergence and maintenance. Savage, Fisher, and Birch (2007) verified parental influence on children's eating habits through the food offered to them by parents, not only by the type of food, but also by the amount. This study recommends that parents should become more aware of their influence and apply new strategies to intervene in children's food preferences, for there are works associating the parents' push and control with the less fruits and vegetables intake. Another very influential factor on children's eating habits connected to family life is marketing, as children on average watch five hours of television per day (Moura, 2010).

Eckstein et al. (2006) have studied the perception of parents who have obese and overweight children and came to the conclusion that parents who recognized their children were overweight were more likely to be concerned about them. These authors pointed out the benefits of identifying health orientations to increase parents' concern and awareness, with the purpose of improving their adherence to programs targeting 
overweight children. Boa-Sorte et al. (2007) have done comparative research between maternal perception and children's self-perception and verified that lack of appropriate perception between mother and child was likely presented in cases of excessive weight. Other studies also evaluated parents' perception and confirmed that many of them distorted the nutritional condition of their obese children. This distortion was even more pronounced in cases of young children's parents (Macedo, Festas, \& Vieira, 2012; Tenorio \& Cobayashi, 2011).

The advantages of including parents in childhood obesity treatment are already recognized. Golan, Weizman, Apter, and Fainaru (1998), for example, conducted research that compared the conventional treatment with a treatment regime carried out with obese children's parents, focusing on the children. There was greater weight loss in children and lower rates of discontinuance in the parents' group, highlighting the importance of parents in childhood obesity treatment. Therefore, the results revealed that the treatment involving parents was more effective than conventional treatment in many respects, including cost savings. The habits adopted by parents, as well as those applying to the children's other social environments, also become targets of change in the case of obesity prevention. Carvalho et al. (2013) argue that: "The intervention in the family environment begins early, in intrauterine life, stimulating a healthy diet from birth onwards and physical activity starting in the initial months of life" (p. 81).

The habits modeled by parents in the day-to-day of the family influence the risks to children's health. Haines et al. (2013) evaluated the effectiveness of interventions that changed home routines in association with the risk of obesity in children between two and five years old from low-income families. The decrease of BMI (body mass index) was observed in families participating in the motivational intervention called "Healthy Habits, Happy Homes" that consists of encouraging families to adopt healthy habits. The effects of this intervention on children included an increase in sleeping time and a decrease in time spent in front of the television.

Regarding the parents' relationships in families with childhood obesity, Schmeer (2012) found an increase of BMI and risk of excess weight and obesity in children of three to five years old with mothers who were separated or lived without a mate for two years or more. The study states that not all separations are harmful to children, but it suggests that presence of the mate represents protection from the risk of obesity to the child, even though the same doesn't apply to the mother, who tends to gain weight in cohabitation.

The works presented above highlight eating habits and physical activity in childhood obesity. On the other hand, they do not target the analysis or comprehension of the family organization and function from the point of view of system theory, although they underscore the importance of parents' involvement in the treatment of childhood obesity. The positive outcomes of system interventions are confirmed by Flodmark and Ohlsson's study (2008), in which the results of family therapy were $40 \%$ more effective than conventional treatment (including checkup and nutritional counseling). It is worth mentioning that the intervention chosen in this research used techniques that gave the family the responsibility of changing their lifestyle, where the therapist takes the position of facilitator. Tassara, Norton, Marques, and Walter (2010) also understand that the socio-family context, not the child, is responsible for the obesity. Thus, treatment should provide relational changes through a co-construction between family members and professionals of the multidisciplinary team.

An intervention that includes the family presupposes familiarity with the couple's and the family's dynamics. Accordingly, this article aims to present data about a family participating in psychosocial counseling for families of obese children and adolescents. It comprises part of wider research involving 30 families in 
these conditions and seeks to construct a methodology of counseling to include the whole family of children and adolescents diagnosed with obesity (Ribeiro, 2013). The data discussed in the present work were collected through a family life cycle interview, one of the research activities. The family also participated in the multi-family group that involved four other families, but this activity's data will be presented on another occasion.

\section{Method}

The method elected in this study is the qualitative method, an effort against logical positivism and to encompass the complexity of the human being (M. C. Dessen, Silva, \& M. A. Dessen, 2009). For Martins (2008), it is increasingly common for scientific studies to be oriented by qualitative evaluation, featuring description, comprehension and interpretation of facts and phenomena. Minayo (1994) states that this kind of research facilitates understanding and interpretation of reality, dealing with the whole universe of meanings, motivations, values and attitudes, i.e., a deeper space of relations.

This method was selected for this case study and is justified due to the complexity of the phenomenon and our interest in a deeper analysis of the topic. This kind of study is characterized as a research strategy by allowing the study to investigate deeper phenomena from many angles (Roesch, 1999). Confirming this idea, Gil (1999) points out that the case study is marked by deeper and exhaustive examination of a small number of objects, in order to allow for wider and more detailed knowledge, a task almost impossible in other methods considered.

\section{The Participating Family}

The family is formed by the father Robert (all names used are fictitious), a 43-year-old landscaper; the mother Mary, a 36-year-old homemaker, and the daughter Sofia, a third grade student 10 years of age, obese, currently 178 pounds and 4 feet 1 inch tall. Sofia is dyslexic and has many difficulties in school. Sara, Mary's sister, lives temporarily with the family. The couple has been married for 12 years, lives in their own home in a region of Brazil's Federal District, and has a monthly income of US\$ 363 (about four times of the federal minimum salary). Mary has a 16-year-old daughter from her first marriage who has two children, a boy of 18 months and a girl one month old. She is the third daughter of four siblings and has a very close relationship with her 40-year-old sister, Sara. This sister was present in the interview and answered most of the questions put to the mother, showing intimacy with the nuclear family and knowledge of the couple's affairs.

\section{Instruments}

A family life-cycle semi-structured interview was used to collect data, with questions involving the whole family's history, since the beginning of the parents' relationship until the present, mainly focusing on issues about the children's and family's dietary habits. We also used a genogram (Carter \& McGoldrick, 1995), a graphic representation of family, containing all members' age, kinship and roles.

\section{Procedures}

The family was referred to us to participate in the research by the Nutrition Program of the Catholic University of Brasília, where they were being counseled. After the referral, the family was contacted by telephone and the interview was scheduled. The mother Mary, the sister Sara, and the child Sophia, who was diagnosed with obesity, were present. Mary signed the Free and Informed Consent Agreement, which had been approved previously for the research project by the Research Ethics Committee of Catholic University of 
Brasília. The interview was based on an outline created for this purpose, lasting 60 minutes, and the audio was recorded for later transcription.

\section{Data Analysis}

The interview data were transcribed and interpreted in light of qualitative epistemology, supported by three principles: (1) Knowledge is a constructive-interpretative process; (2) The production process of knowledge has an interactive character; and (3) The meaning of singularity as legitimate level of knowledge. The qualitative investigation, founded on qualitative epistemology, is not designed to produce final outcomes that can be taken as universal and unchanging references about the subject, but to produce new theoretical moments that can be joined organically to the general process of knowledge production (González Rey, 1999).

Data analysis has three phases, according to González Rey (2010): (1) pre-analysis: The data are read and reread until the content and meaning are apprehended by the researcher; (2) indicator collection: Elements given meaning through the investigator's interpretation are constructed on the base of implicit and indirect information; and (3) construction of zones of meaning: Zones of outcome synthesis that summarize the indicators found.

\section{Outcomes and Discussion}

The data analysis allowed the construction of three zones of meaning that will be presented and discussed below.

\section{Zone of Meaning 1:"Sofia Was Born Fat": The Beginning of Obesity}

The mother and the aunt described Sofia as a baby who was already born fat, a kind of baby that attracts everybody's attention. According to the aunt:

She was born large. She was always a large child. Always overweight, since she was a baby. She was never a little baby with a little waist, was never a petite thing. She was a strong little baby, the type people see and say "Oh what a beautiful baby"...

Mary breastfed Sofia until her fourth birthday, and then fed her with baby bottle, but did not report when she began to introduce other kinds of food. Currently, Sofia usually drinks soda instead of eating. About the soda, Mary added that she has a one-year-old grandson who does not drink a bottle, but is "addicted to Coke"; she said:

He looks at a (soda) bottle and complains! A one-year-old baby pushes us to go there and fill his bottle. Look at this, his intelligence is amazing.

Mary attributes his behavior to intelligence and does not seem to be aware that offering soda to a very young child is inappropriate behavior for adults.

The child's diet is the responsibility of the adults who take care of them. They buy, choose, prepare and offer the food to the child, thus, mold habits that can be healthy or not. Mary and Sara's calling Sophia a "fat baby" is seen as something positive; they do not see how this can represent a risk to the child's health. These data lead Tassara (2012) to declare that there is a social belief related to diet, whereby playing the role of mother is to nurture the child, and the relationship between parents and children is based on the following belief: If the child is thin, the parents are not taking care of the child; it is starving. Even though there are many awareness campaigns about the importance of a healthy diet, this belief is still strong in Brazil. Other authors, 
such as Savage, Fisher and Birch (2007), also refer to the influence of parents in type and amount of food ingested by children.

The perception of parents about the obese child is also important in his/her treatment, for when there is no awareness about excess weight and the risks associated with it, this complicates the success of prevention and treatment, even as the resultant decrease of obesity prevalence in childhood (Tenório \& Cobayashi, 2011). According to the author, to facilitate this perception a better understanding of factors associated with parents' behavior is necessary to stimulate their closer engagement in obesity treatment. Other studies also evaluated the parents' perception of children's weight and revealed that those who recognize the children's weight problem were more susceptible to be concerned about their children (Eckstein et al., 2006). Macedo, Festas, and Vieira (2012) report a significant sample of parents show distortion in relation to their children's nutrition and state of obesity, a distortion that was even higher among younger parents. Based on these data, Fisberg (2005) states that the treatment of childhood obesity should include general changes in parents' and children's attitudes, in relation to eating habits, lifestyle, physical exercise, and long-term alimentary correction.

Sofia was already obese when she started school and had problems, because she did not tolerate being called "fat" by schoolmates. The family says that in this phase she started being reclusive, so they decided to take her to a nutritionist. According to Mary, at the beginning they took care with her diet, but later Sofia only ate whatever she wanted and rejected healthy food. From this time forward, mother and aunt failed to give attention to her diet.

She was already fat when she came to school. It was a tough period, because she did not tolerate being called fat by the other kids, and she became reclusive because of this. We were also being counseled by a nutritionist... I managed in the beginning, we took care of her diet, but she was growing up and did not want to keep on eating what she was supposed to eat... So she went ahead and gave it up.

Obese people, including children, are frequently victims of bullying, mostly in family and school. Children participating in this research report nicknames and insults related to their weight, not only by schoolmates and friends, but also in the family, such as jokes by siblings and even parents.

Sofia's sister has two children. According to Sara, the relationship between them was very nice, but when the children came along, Sofia's niece and nephew, she became quiet and reclusive, something noticed even by the teacher. Sara comments:

I went to her school to talk to the teacher because when I do homework with her, I was surprised... I went there to have a conversation, and so they told me she suffered when her nephew was born... She started crying more, eating more and became sensitive. Every word spoken to her made her cry.

According to Sara, Sofia is a very reclusive child in school. A psycho-pedagogue was available to help her in solving this problem and diagnosed the dyslexia. She does not read yet, and her father and aunt try to help her in school. The issue of obesity seems to point to the rise of other problems in school that have damaged her development, such as poor socialization, weak school performance and troubles with schoolmates.

With the purpose of highlighting the importance of the relationship between family members and other systems, Minuchin and Fishman (2003) call our attention to the fact that families are multi-individual systems of extreme complexity, but are subsystems of wider unities, like the extended family, the neighborhood, school and the society as a whole. The interaction with these wider subsystems, or holons, as they are also called, produces a significant part of the family's problems and responsibilities. 
The teacher said that all the time she is reclusive, she doesn't like to play, doesn't take a walk, doesn't participate in anything. The school has done what it can, and there is nothing else to do.

According to Mary, Sofia suffered when her niece and nephew were born, showing a change of behavior. System theory treats the family as a live organism, dynamic, in continuous oscillation, tending towards (re)equilibrium and able to reach new levels even more complex (Minuchin, 1982). This flotation compared to the live organism can be already noticed in early stages of the family rise, for the system responds to predictable and unpredictable stressors that produce anxiety, especially on family life-cycle transition points (Carter \& McGoldrick, 1995).

Bradt (1995) points out that the family life-cycle event that has the greatest impact on the nuclear family is the birth of a child and emphasizes the importance of a closer relationship between parents in the task of taking care of the child. Possibly the birth of the niece and nephew took more of the adults' time and attention and, for this reason, the child felt depreciated and rejected, which led her to become more reclusive, including in school. Her eating habits were also affected, after the birth of the children, according to the mother. The family noticed these changes, as confirmed by the school, but did not take measures to solve or ameliorate the problems. The mother refers to her "neglect" of her daughter's diet, at the time she began to reject the food offered to her. This should not happen, for it is the function of the parents and/or adults in the family to care for, orient, protect and educate the children. In this family, the parental role collapsed, which will be discussed in the following section.

\section{Zone of Meaning 2: "I Let Her Eat": Difficulty in Limiting Children}

Asked about what the family thinks about eating, Mary recognizes that her diet is wrong, but she does not care and, thus, let Sofia eat whatever she wants. She knows this eating pattern can harm her daughter's health, but "I do not think about it".

It's wrong ... But I don't care about this food stuff. I let her eat. Sofia, for example, if she eats and there is Coke and I say "Sofia, have lunch first and then you can drink soda", she can skip the food, because she is autonomous. She does it, period!

As the interviewer called the mother's attention to Sofia's diet and to other health problems obesity that can bring, Mary said she's aware, but didn't know what to say to change this situation. She considers it her obligation to provide her husband's meals because he works.

I don't think about it... Cause I don't let him go without food, because in my opinion he has to have his food because he works. So, I think it's my obligation to prepare the food he's going to take with him.

Once more we see the family's neglect related to the diet of the child. Mary seems to be more worried about the husband's diet than daughter's, as if she didn't feel able to carry out both functions and had to choose one of them. This neglect is not only about the matter of nutrition, but other dimensions of the child's life, too; according to the mother, she doesn't impose rules regarding eating or sleeping times, leaving the child to decide on her own how she's going to take care of herself. About her routine, the mother says:

She stays awake until midnight, and so you go to the refrigerator... Get a yogurt and something else. We say she should eat 2 or 3 cookies only, so she gets angry and doesn't eat anything. When she feels like it, she sneaks there and eats an entire package. She likes to eat potato chips and cookies like Prestigio (coconut), Passatempo (chocolate)...

For Minuchin (1982), parents should be able to nurture, control and guide, using authority when necessary, 
and should preponderate the hierarchy of parents over children. These relations, according to the author, suffer changes with the growth of the child, and the functions and rules need to be adjusted for each stage of development. We can see in this family an inability on the part of the parents to perform parental functions, mainly in this important moment of the life cycle, which can result in more serious consequences related to obesity, as well as to health and family development as a whole.

On the other hand, Mary states she recognizes that her daughter needs help:

I'm going to help her, because she needs my help... I think I'll succeed... Because it wasn't like this I'm better, I'm feeling I'm better, I got to take care of her.

Sofia says that she eats whatever she wants. She knows she should eat less to lose weight, but doesn't think she could change anything in her diet: "I want to keep eating whatever I want". The mother says, "Everything she wants is fatty. She sneaks to the refrigerator, that's why she's like this. At home, for example, we buy the pizza she likes, but if she has to eat rice she might refuse".

Mary and Sara say that there are no clear rules, in general, in the family. Those that exist and are followed are defined by Sara, indicating that this family depends on an external member to establish limits. It is in this moment of the family life cycle, i.e., a family with young children, that parents experience difficulties: In general, they don't accept the generational boundary between them and their offspring, while at the same time they complain about the struggle to control the children and establish limits, hoping that children will behave like adults (Carter \& McGoldrick, 1995). On the other hand, Sara says that Sofia does not respect her in some situations:

Except someone goes there and turns off the light, like I did with the shower today, I went there and turned off the shower, and so my sister came and clutched at straws. She eats everything she wants, and if she says, "I won't take a bath right now", she won't. If she goes to the computer and says, "I'm staying right here", she will and nobody takes her away.

According to Mary, food is used to compensate the father's lack of attention. Before, the father used to take a walk with the daughter, was kind, gave her gifts, but now it's all compensated with soda, cookies with filling, and instant noodles. The aunt agrees that the absence of the father is compensated with food:

I say they reward Sofia with food. He says he doesn't do anything, and she answers: "Daddy, then give me this". And they go to the market and buy whatever she wants.

According to Otto (2007) and Otto and Ribeiro (2012), hunger is the physiological expression of the body's need for energy, while the appetite is the psychological desire to eat, which can give someone an anticipatory and particular pleasure. Hunger produces appetite, but the appetite can exist independently and can be stimulated by other means, i.e., a person's emotional state is reflected by appetite. Therefore, for obese individuals, the act of eating is felt as a relaxant, as a way to situate anxiety and anguish, given difficulties in dealing with frustration and limits. Food can be used as well to punish or gratify people, as we saw in the statement of Sara, who believes that Sofia's father gives her food when he feels distanced from her. The food acquires an emotional value and gains the functions of bringing people affectively together and attempting to create or straiten bonds between family members.

\section{Zone of Meaning 3: "Sofia Sleeps With Them...": The Mother's Illness as a Complicating Factor of the Husband-Daughter Relationship}

Robert and Mary have been married for 12 years. She says that in the beginning of the relationship, the 
couple was very close, but after the birth of Sofia, they started become distant, as the girl always slept in their bed. When asked about the marital relationship, Mary answered that it was good, but then the sister spoke up and said:

It's useless to hide it... They're a couple, but since Sofia was born she sleeps with them, and now Sofia is grown up and is not used to sleeping alone. Their life as a couple is a little frayed by the lack of intimacy.

About parenthood and conjugality, Carter and McGoldrick (1995) state that the presence of children in the first stages of the family life cycle impedes the formation of an exclusive partner-to-partner relationship preceding the parent function; however, the space of every subsystem needs to be maintained, and in the family studied, we see a clear problem of delimiting the boundaries that give protection and define family roles, putting, in this case, the subsystems' healthy functioning at risk.

Mary had anorexia nervosa when she became pregnant with Sofia and then depression. She's still in treatment and believes it influences their relationship. She compares it to the way she raised her first daughter:

With the other, "no" meant "no", but with Sofia it's different, I need to repeat something three or four times and get angry or serious, or else she disobeys me.

She associates this lack of authority with the fact of being sick when she got pregnant with Sofia.

When I got pregnant with my daughter I got sick, I had anorexia, and I'm still in treatment... I get a little lax with the medications, and then Sofia doesn't obey what I say... I let her do what she wants to avoid getting upset. I don't know how to educate Amanda, but this isn't what I want. I need help too. Because if she's so fat, I guess it's not a good thing... she makes her own food, gets by...

About the participation of her husband in their daughter's education, Mary says that she doesn't count on him, because "he's on his own, working and getting home at night, tired ... He speaks very little, to hear something at home we have to turn on the radio or something else". Mary says Sofia complains that her parents don't go out with her. The girl doesn't have friends or relate to schoolmates. According to the mother, the girl doesn't like to be with others:

When I got sick she became this way, we were living together, just the two of us. She's embarrassed, and I guess she's depressed too. I'm paralyzed. I don't want to go anywhere. I guess it's because of depression. I don't like visiting neighbors or doing anything. So, that's what I'm passing on to her. My life, my routine is to take care of the house and lie down, just that! I take medication everyday.

Her sister said Mary's health problems also influence the couple's relationship:

Their life as a couple is a little frayed by a lack of intimacy... Couple's stuff, like you get home at night and talk. The time they talk most, I noticed, is during breakfast. They wake up at the same time, and they have contact at that time. They talk about things at home, when they are together.

About the relationship with the husband, Mary says:

It's true that she still sleeps with me. My husband sleeps in the other bedroom. After she was born, he wanted to do it, and then it continued when she grew up... and when we talk about taking her out of our bed, like now that my grandson's bedroom is empty, then I said: "Sofia, now I'm going to make your bedroom here". But she never likes the idea. "Oh! Mommy now I want my own bedroom"- She doesn't say it... so I don't feel comfortable taking her out of the bed yet, because she feels alone.

When Mary talks about her past, mentions that she had anorexia nervosa when she became pregnant with 
Sofia and still has depression, and that she takes medication and has medical checkups, we perceive her emotional condition and fragility. She recognizes her incompetence in taking care of her daughter and complains about her husband's distance, in that he's away from home for so long and has poor communication with her.

In view of this, we see a couple with a damaged relationship, with no commitment in the fulfillment of parental functions. For family therapists, parents are responsible for promoting health and the healthy development of children and the family as a whole. Minuchin and Fishman (1990), for example, states that parents should adapt as children grow up, taking into consideration the changing needs of their offspring, giving them more autonomy, without losing the right of establishing limits and caring for the family as a system. He synthesizes the parental adaptation throughout childhood development in these words: "Adults who established educational patterns should now change them, developing appropriate methods to keep control, even as they encourage growth" (p. 34).

The fact that Sofia still sleeps in her parents' bed leads us to Bowen (2013), who developed the concept of triangle. In this case, we could say that Sofia would be "triangulated" with her genitors, since she performs the important role of intermediating the relationship between father and mother. The function of the child in the homeostatic mechanism of the family is well described by the author. Bowen (2013) understands that the "problem of 'triangulated' child represents one of the most serious difficulties in family psychotherapy" (p. 62). For the author, it's a projection of family problems onto the child and happens frequently in the regular functioning of systems. However, when it happens intensively, parents cannot distinguish the child's problems and convert the couple's experience in a poor life experience.

We understand that couples with parental and marital issues may let the child take a place in their bed. This is strong evidence that a relationship needs more attention and that the couple may not be prepared to solve their issues, choosing a child to divert focus from marital troubles.

Parents are seen in terms of their parental functions as the agents for the promoting of changes in the eating behavior of the child, but there are few descriptions of conjugal dynamics in this specific context. Satir (1993), for example, makes clear the influence of conjugal conflict in parental functions, an area still under-researched in studies of childhood obesity. If the couple is in constant conflict, the parental rules which should define what would do and who would be the child will certainly be affected (Satir, 1993, p. 61).

The parental subsystem, in this family, should be consolidated, for a spirit of unity of the couple is essential in guiding the family as a whole, as it is considered the axis of family relations, indispensable to the coherence between what they think and what they do for the general welfare. Although the challenge is great and their responsibilities go further, they should seek to be role models in their actions and standards that afford, mainly for the children, affective and emotional security. The couple needs to care for themselves as the family subsystem responsible for promoting health (Ribeiro, Nogueira, Melo, \& Valadares, 2013).

\section{Conclusions}

The data analysis leads us to identify the following features in the dynamic of the family studied, which can be related to the child's obesity: parental neglect towards the child's diet and other behaviors; the interference of the aunt in the family's routine, including in the child's education; genitor illness complicating the fulfillment of parental functions; difficulties in the parents' conjugal relationship; the lack of a unified spirit in the parental couple, making the necessary commitment to the child's education and protection difficult; and 
family resistance to accept and engage in treatment of their child's obesity.

After the interview with the family, three other activities were proposed as continuance of the research project: family, multi-family group, and children's group psychotherapy. The family didn't come to all activities, demonstrating resistance to accept and engage in treatment. Family psychotherapy was offered when the research group identified concerns: for the child, who was more obese each meeting; mother, who appeared fragile; and the father, whose distance was evident in his absence from all but one session. However, the family came to the first meeting scheduled and the mother told us, by telephone, that she was unmotivated and that the father couldn't come due to work. The non-acceptance of counseling offered by the research group showed family opposition to accepting the gravity of the daughter's problem and to taking action to protect and orient her. These data confirm, in our view, that childhood obesity treatment should take into account these features of the family dynamic.

We believe that the responsibility for the problem of childhood obesity is not the child's, but of the social-family context. Therefore, treatment should essay relational changes in the whole system through a co-construction between family members and professionals of a multidisciplinary group. Studies have shown that childhood obesity treatment with family therapy is more effective than conventional treatment (which includes medical checkups and nutritional counseling). It's worth mentioning that the intervention adopted in studies has used techniques which give the family the responsibility to change their lifestyle, establishing the researcher/therapist as facilitator. The participation of other professionals from medicine and nutrition is also important, for achieving the necessary changes will only be possible by a co-construction between family members and professionals of a multidisciplinary group.

\section{References}

Bowen, M. (2013). De la familia al individuo (5th ed.). Barcelona: Paidós.

Boa-Sorte, N. et al. (2007). Percepção materna e autopercepção do estado nutricional de crianças e adolescentes de escolas privadas. Jornal de Pediatria, 83, 349-356.

Bradt, J. O. (1995). Tornando-se pais: Famílias com filhos pequenos. In: B. Carter, \& M. McGoldrick (Eds.), As mudanças no ciclo de vida famíliar (2nd ed.). Porto Alegre: Artmed.

Brazil. Ministry of Health. Secretary of Vigilance in Health. Vigitel Brazil. (2013). Vigilance system of chronic disease risk factors by telephone survey (p. 132). Ministry of Health, Secretary of Vigilance in Health, Brasília: Ministry of Health.

Camargo, A. P. P. M., Barros Filho, A. A., Antonio, M. A. R. G. M., \& Giglio, J. S. (2013). A não percepção da obesidade pode ser um obstáculo no papel das mães de cuidar de seus filhos. Ciência \& Saúde Coletiva, 18(2), 323-333.

Carter, B., \& McGoldrick, M. (1995). As mudanças no ciclo de vida familiar: Uma estrutura para a terapia familiar. In B. Carter, \& M. McGoldrick (Eds.), As mudanças no ciclo de vida familiar (2nd ed.). Porto Alegre: Artmed.

Carvalho, E. A. A. et al. (2013). Obesidade: Aspectos epidemiológicos e prevenção. Revista Médica de Minas Gerais, 23(1), 74-82.

Dessen, M. C., Silva, S. C., \& Dessen, M. A. (2009). Pesquisa com famílias: Integrando métodos quantitativos e qualitativos. In L. Weber, \& Dessen, M. A. (Eds.), Pesquisando a família: Instrumentos para coleta e análise de dados. Curitiba: Juruá.

Eckstein, et al. (2006). Parents' perceptions of their child's weight and health. Pediatrics, 117(3), 681-690.

Fisberg, M. (2005). Atualização em obesidade na infância e adolescência. São Paulo: Atheneu.

Flodmark, C. E., \& Ohlsson, T. (2008). Childhood obesity: From nutrition to behaviour. Proceedings of the Nutrition Society, 67(4), 356-362.

Golan, M., Weizman, A., Apter, A., \& Fainaru, M. (1998). Parents as the exclusive agents of change in the treatment of childhood obesity. American Journal of Clinical Nutrition, 67(6), 1130-1135.

González Rey, F. (1999). La investigación cualitativa en psicología: Rumbos y desafios. São Paulo: EDUC.

González Rey, F. (2010). Pesquisa qualitativa e subjetividade: Os processos de construção da informação. São Paulo: Cengage Learning. 
Gil, A. C. (1999). Métodos e técnicas de pesquisa social. São Paulo: Atlas.

Haines, J., McDonald, J., O’Brien, A., Sherry, B., Bottino, C. J., Schmidt, M. E. et al. (2013). Healthy habits, happy homes: Randomized trial to improve household routines for obesity prevention among preschool-aged children. JAMA Pediatrics. Retrieved October 12, 2013, from http://archpedi.jamanetwork.com/article.aspx?articleid=1735654

Kunkel, N., Oliveira, W. F., \& Peres, M. A. (2009). Excesso de peso e qualidade de vida relacionada à saúde em adolescentes de Florianópolis, SC. Revista de Saúde Pública, 43(2), 226-235.

Macedo, L., Festas, C., \& Vieira, M. (2012). Percepções parentais sobre estado nutricional, imagem corporal e saúde em crianças com idade escolar. Revista de Enfermagem Referência, v. ser III, 191-200.

Martins, G. A. (2008). Estudo de caso: Uma estratégia de pesquisa. São Paulo: Atlas.

Minayo, M. C. S. (1994). O desafio do conhecimento: Pesquisa qualitativa em saúde. São Paulo: Hucitec.

Minuchin, S. (1982). Famílias: Funcionamento e tratamento. Porto Alegre: Artes Médicas.

Minuchin, S., \& Fishman, H. C. (1990). Técnicas de terapia familiar. Porto Alegre: Artes Médicas.

Moraes, P. M., \& Dias, C. M. S. B. (2012). Obesidade infantil a partir de um olhar histórico sobre alimentação. Interação em Psicologia, Curitiba, 16(2), 317-326.

Moura, N. C. (2010). Influência da mídia no comportamento alimentar de crianças e adolescentes. Revista Segurança Alimentar e Nutricional, Campinas, 17(1), 113-122.

Otto, A. F. N. (2007). Obesidade e transtorno da compulsão alimentar periódica—Um estudo sobre a dinâmica familiar (Master dissertation presented to the Postgraduate Program in Catholic University of Brasília, 192f).

Otto, A. F. N., \& Ribeiro, M. A. (2012). Unidos em torno da mesa: A dinâmica familiar na obesidade. Estudos de Psicologia, Natal, 17(2), 255-263.

Ribeiro, M. A. (2013). Construção de metodologia de atendimento psicossocial de crianças e adolescentes com transtornos alimentares e suas famílias (Research project of Master and PhD's program of Catholic University of Brasília—financial resources from $\mathrm{CNPq} / \mathrm{CAPES})$.

Ribeiro, M. A., Nogueira, H. F., Melo, V. A. A., \& Valadares, F. S. A. (2013). Pesquisa e intervenção com famílias de crianças e adolescentes com obesidade utilizando a metodologia do Grupo Multifamiliar. In: A. Garcia, M. D. C.Macedo, \& T. A. Nunes (Eds.), Relações interpessoais e saúde (pp. 55-67). Vitória: CIPRI-UFES.

Roesch, S. M. A. (1999). Projetos de estágio e de pesquisa. São Paulo: Ed. Atlas.

Savage, J. S., Fisher, J. O., \& Birch, L. L. (2007). Parental influence on eating behavior: Conception to adolescence. Journal of Law, Medicine \& Ethics, 35(1), 22-34.

Satir, V. (1993). Terapia do grupo familiar (5th ed.). Rio de Janeiro: Francisco Alves.

Schmeer, K. K. (2012). Family structure and obesity in early childhood. Social Science Research, 41(4), 820-832.

Tassara, V. (2012). Obesidade na infância e interações familiares: Uma trama complexa. Belo Horizonte: Coopmed.

Tassara, V., Norton, R. C., Marques, C., \& Walter, E. U. (2010). Importância do contexto sociofamiliar na abordagem de crianças obesas. Revista Paulista de Pediatria, São Paulo, 28(3), 309-314.

Tenorio, A. E. S., \& Cobayashi, F. (2011). Obesidade infantil na percepção dos pais. Revista Paulista de Pediatria, $29,634-639$.

World Health Organization. (2014a). Obesity and overweight. Retrieved February 20, 2014, from http://www.Who.Int/Features/ Factfiles/Obesity/Facts/En/Index1.Html.

World Health Organization. (2014b). 10 facts on obesity. Retrieved February 20, 2014, from http://www.who.int/features/factfiles /obesity/facts/en/index 1.html 